\title{
Friction welding of Aluminium Alloy 6063 with copper
}

\author{
Yashwant Chapke ${ }^{1,{ }^{*}, \text { Dinesh Kamble }}{ }^{1}$, and Saoud Md. Salim Shaikh ${ }^{2}$ \\ ${ }^{1}$ Vishwakarma Institute of Information Technology, Pune 411048, India \\ ${ }^{2}$ Sinhgad Academy of Engineering, Pune 411048, India.
}

\begin{abstract}
Friction welding process is a forging welding process in which work piece are joined due to heat produced by friction between two joining surfaces and upset pressure is applied by non-rotating work piece. Joining of aluminum alloy with dissimilar material is important research area to focus on as maximum aircraft structures havexx Aluminum alloy frame and aerospace designers familiar with Aluminum alloy and its design considerations. After comparison of mechanical properties and application of light weight alloys aluminum alloys, tungsten, stainless steel and copper, copper selected as dissimilar material to join with Aluminum alloy AA6063. AA 6063 also known as architectural alloy selected based upon its properties. This dissimilar joint of AA6063 and Copper has application in electrical conductors as copper is good electrical conductivity and used in maximum electrical conductors. In this research work AA6063 joined with Copper successfully using Rotary Friction Welding process. Through process study effective process parameters like Friction Pressure, Upset Pressure, Spindle Speed, and Friction Time identified and their effect on weld joint strength were studied.Testing for measuring UTS of friction welded joint conducted. Using DOE tool optimized set process parameters for friction welding identified and their effect on weld joint strength studied experimentally. Maximum UTS of $222.787 \mathrm{MPa}$ for Friction welded joint achieved, bend test also performed on friction welded samples.
\end{abstract}

\section{Introduction}

Rotary friction welding is used for joining of round parts like engine valves, steering rod, shafts and other parts in aerospace application. Bimetallic valves are produced using RFW process.

RFW process is solid state joining approach hence limitation of fusion welding of joining different material of different melting point overcome using Friction Welding. In this friction welding process despite of different melting point both AA 6063 and Copper joined which was not feasible earlier by fusion welding process. Aerospace Industry use Aluminum alloy as primary material for structure and frame due to its light weight and mechnaical properties hence Aluminium alloy selected as one material for this research work [1].

Also in aerospace, automobile, marine, defense equipment appliances for joining various copper electrical parts to Aluminum Alloy alloy frame. Mainly in aerospace structures frames made up of Aluminum Alloy and various other metals parts to be joined to Aluminum Alloy frame using friction welding.

\section{Literature Review}

Various Researchers aimed at achieving maximum UTS for friction welded joint through parametric optimization of friction welding process.[1-17] While doing parametric optimization following parameters are considered by researchers,

Friction Time (FT), Friction Pressure (FP), Spindle Speed (SS), Burn of length (BOL)[1-9]. Further sub branching of friction welding parameters can be done in form of upset time, upset pressure, breaking time [1-7]. Researchers focused on study of microstructure of friction weld joint under electron microscope and micro structural characterization done for friction welded dissimilar metal joints. Researchers also stated interested observations by microstructure study of joints in regards to new layer formation and grain structure at welded joint. Mumin Sachin et al found Friction Time, Friction Pressure have direct effect on tensile strength of joint[5]. C. Meengam et al joined semi solidAA7077 using RFWprocess[2]. L.Zhou et al in their research work considered Rotational Speed as dominant parameter and studied its effect on mechanical properties, on microstructure of Ti-6Al-4V. They have observed along

*Corresponding author: yashchapke@gmail.com 
with increase in rotational speed hardness in weld zone decreases. In conclusion remark made by researcher through this study in regards to defect free welds are produced by employing rotational speed ranging from 400 to $600 \mathrm{rpm}$. Researchers through this research work found that 6061 T6 Aluminum can be successfully joined with steel AISI 1018 Steel getting tensile strength in range of $170 \mathrm{Mpa}$ to $250 \mathrm{Mpa}$ for welded joint. J. Romero et al in their research work have done investigation on effect of forging pressure on microstructure and micro hardness of welding joint $\mathrm{Ti}$ $6 \mathrm{Al}-4 \mathrm{~V}[11]$.

\subsection{Difficulty in joining AA6063 with Copper}

Aluminum Alloy 6063and copper has different melting point temperature, Aluminum Alloy 6063 has $610^{\circ} \mathrm{C}$ Melting Point where as Copper has $1024^{\circ} \mathrm{C}$ Melting temperature.

Melting Temperature difference and other factors like formation of intermetallic layer and oxides makes conventional fusion welding of Aluminum Alloy 6063 copper joining obsolete and impractical.

\section{Table 1.0}

Material Comparison

\begin{tabular}{|c|c|c|c|}
\hline Material & $\begin{array}{l}\text { Mechanical } \\
\text { Properties }\end{array}$ & $\begin{array}{l}\text { Chemical } \\
\text { composition }\end{array}$ & $\begin{array}{l}\text { Industrial } \\
\text { application }\end{array}$ \\
\hline $\begin{array}{l}\text { Stainless steel } \\
\text { SS304 }\end{array}$ & $\begin{array}{l}\text { Toughness } \\
\text { Durability } \\
\text { Corrosion } \\
\text { resistance } \\
\text { Cryogenic } \\
\text { resistance } \\
\text { Ductility }\end{array}$ & $\begin{array}{l}\text { SS304 minimum } \\
\text { of } 18 \% \\
\text { chromium } 8 \% \\
\text { nickel, combined } \\
\text { with a maximum } \\
\text { of } 0.08 \% \text { carbon }\end{array}$ & $\begin{array}{l}\text { Aerospace } \\
\text { Automotive } \\
\text { oil \& gas } \\
\text { industries } \\
\text { kitchenware } \\
\text { consumer } \\
\text { products }\end{array}$ \\
\hline Titanium alloy & \multicolumn{2}{|c|}{$\begin{array}{l}\text { Very high tensileTitanium alloy } \\
\text { strength and has } 6 \% \text { aluminum } \\
\text { toughness at higland } 4 \% \\
\text { temperature alsovanadium, } 0.25 \\
\quad \% \text { maximum } \\
\text { iron, } 0.2 \% \text { oxygen } \\
\text { and remaining } \\
\text { titanium }\end{array}$} & $\begin{array}{l}\text { Military } \\
\text { Aircraft } \\
\text { Spacecraft } \\
\text { Bicycle } \\
\text { Connecting rod } \\
\text { Consumer } \\
\text { electronics } \\
\text { Medical } \\
\end{array}$ \\
\hline Copper & $\begin{array}{l}\text { Soft } \\
\text { Malleable } \\
\text { Ductile } \\
\text { High thermal } \\
\text { electrical } \\
\text { conductivity }\end{array}$ & $\begin{array}{l}\text { Copper available } \\
\text { in nature in } \\
\text { directly usable } \\
\text { metal form }\end{array}$ & $\begin{array}{l}\text { Widely used } \\
\text { nonferrous } \\
\text { metal. } \\
\text { Electronics } \\
\text { Electric power } \\
\text { Machineries }\end{array}$ \\
\hline
\end{tabular}

Stainless Steel, titanium, Copper and Magnesium materials are identified for joining with aluminum alloy. Material comparison done based upon its material properties, chemical composition and industrial application.

Parameters have dominant effect on tensile strength of friction welded joint identified through study.

Following process parameters identified related to RFW process,
Friction Pressure (FP), Upset Pressure (UP), Friction Time (FT) and Spindle Rotation Speed (SS). Following inferences were drawn based upon literature study and pilot experimentation.

1. High Spindle Speed results in good tensile strength of joint

2. High upset pressure will increase hardness of joint

3. Increasing Friction Pressure value results in increase in tensile strength of joint.

\section{Experimentation}

\subsection{Design of Experiments (RSM)}

Three levels low medium and High identified for selected process parameters and Using Response Surface Methods (RSM) optimum set of process parameters obtained and used for conduction of experiments.

For performing DOE Design Expert Tool used and optimum values of Friction Time (FT) 1 second, Spindle Rotation speed (SS) 1800 RPM Friction Pressure (FP) 39 and $48 \mathrm{Kg} / \mathrm{mm}^{2}$ and Upset pressure 97 $\mathrm{kg} / \mathrm{mm}^{2}$ obtained.

\subsection{Experimentation}

Total Nine Trial runs conducted on Rotary Friction Welding Machine. Optimized process parameters sets used for conduction of experiments as per parameters sets obtained from DOE tool. In first two trails Aluminum Alloy 6063couldn't joined with copper alloy due to less Friction Pressure (39Mpa and 48Mpa) and upset pressure (80Mpa and $97 \mathrm{MPa})$. Then for next four trail run as per process parameter obtained from design expert tool and expert advice Friction Pressure and Upset Pressure. Again four more trails are taken using and maximum tensile strength achieved through variation of process parameters. Experimentation performed on Rotary Friction welding Machine having maximum forge force $120 \mathrm{KN}$, maximum spindle speed of 2000 RPM.

\subsubsection{First trail run Experiments}

In this trail run Friction Pressure is used $39 \mathrm{MPa}$ and 48 $\mathrm{MPa}$ respectively, Upset Pressure used $80 \mathrm{MPa}$ and 98 MPa and Spindle Speed maintained at 1800 RPM. 


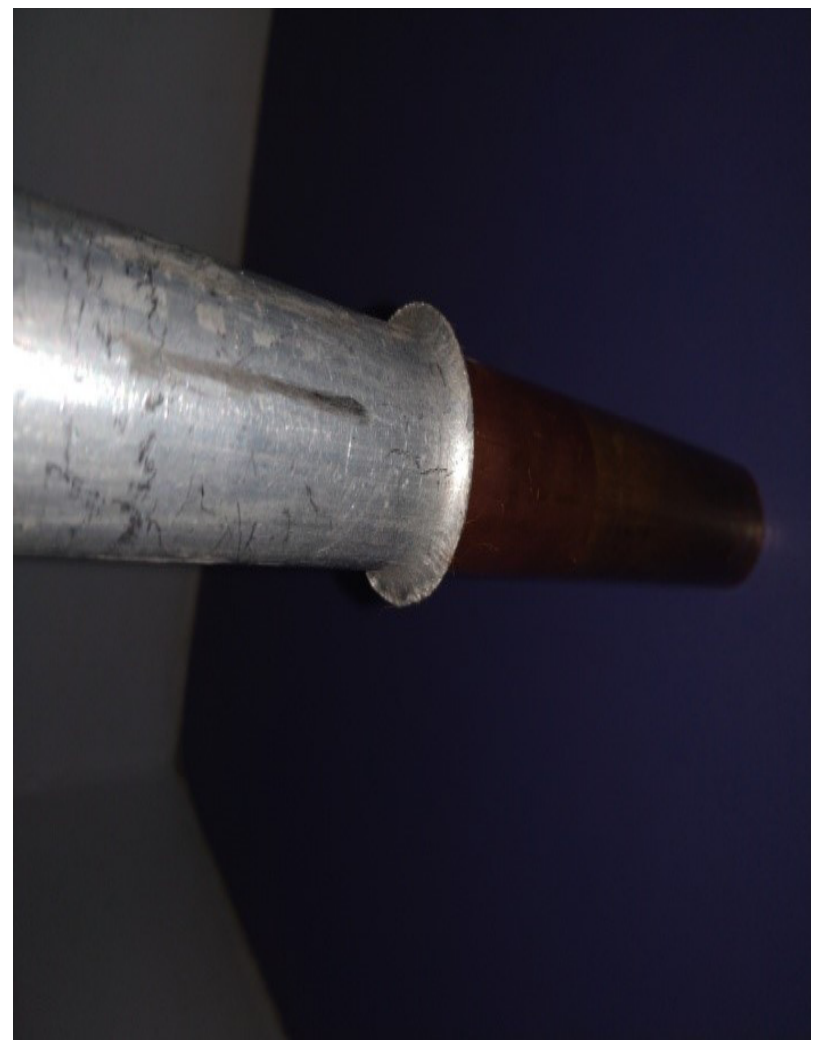

Fig.1.0 First two trailsrunAA6063- Cu Failed

Table 2.0

Process Parameters Set 1 (Failed to join)

\begin{tabular}{lcc}
\hline Parameters & Run 1 & Run 2 \\
\hline Spindle length L1 & 141.6 & 141.6 \\
Slider side L2 & 141.2 & 141.2 \\
Total= L1+L2 & 282.8 & 282.8 \\
Final length $\quad$ (after & 264.2 & 266.2 \\
welding) & & \\
Loss(actual measured) & 18.6 & 16.2 \\
Shrinkage range & 18 & 18 \\
Friction time t1b & 0.5 & 1 \\
Break delay t2 & 0.1 & 0.6 \\
Upset delay t3 & 0.3 & 0.1 \\
Upset time t4 & 2 & 3 \\
Soft friction & 0 & 25 \\
Upset & 80 & 97 \\
pressure@13kg/mm2 & & \\
Feed & 75 & 75 \\
Rpm & 1800 & 1800 \\
\hline
\end{tabular}

Trail run taken with two sets of process parameters. In first run Aluminium Alloy 6063 not welded with copper and this runs become void run. Following process parameters used for first trail run and it is observed that selected values of Friction Pressure needs to be increased for successful weld joint between Aluminium Alloy 6063 and Copper.Aluminium Alloy 6063 not welded with copper and this runs become void run. Following process parameters used for first trail run and it is observed that selected values of Friction Pressure needs to be increased for successful weld joint between Aluminium Alloy 6063 and Copper.

\subsubsection{Second and third trail run Experiments}

With second set of parameters four runs were conducted under second and third trail run. From Parameter set 2 sound friction welded joints produced. But after welding final length received was less hence more losses observed. To reduce losses with same set further trail taken.

In third trial four more trail run with same set of parameters used in second trail run performed. Here actual measured loss was less than second trail run. Final length received after weld also was more than previous trail run which reduces the losses and saving material.

Second and third trial run total eight experiments performed with following set of parameters given in Table No. 3.0

Table 3.0

Process Parameters set 2(successful joining)

\begin{tabular}{lcccc}
\hline Parameters & \multicolumn{1}{l}{$\mathbf{2}$} & $\mathbf{3}$ & $\mathbf{4}$ \\
\hline Spindle length & 140 & 141.6 & 142.3 & 140.8 \\
Slider side L2 & 140.7 & 141 & 140.8 & 140.1 \\
Total= L1+L2 & 280.7 & 282.6 & 283.1 & 280.9 \\
Final length & 268.4 & 267.2 & 276.4 & 277.5 \\
welding) & & & & \\
Loss(actual & 12.3 & 15.4 & 6.7 & 3.4 \\
measured) & & & & \\
Friction time t1 & 1 & 1 & 1 & 1 \\
Break delay t2 & 0.6 & 0.6 & 0.6 & 0.6 \\
Upset delay t3 & 0.1 & 0.1 & 0.1 & 0.1 \\
Upset time t4 & 3 & 3 & 3 & 3 \\
Soft Friction P & 25 & 25 & 48 & 48 \\
Upset Pressure & 97 & 97 & 97 & 97 \\
Feed & 75 & 75 & 75 & 75 \\
Rpm & 1800 & 1800 & 1800 & 1800 \\
\hline
\end{tabular}




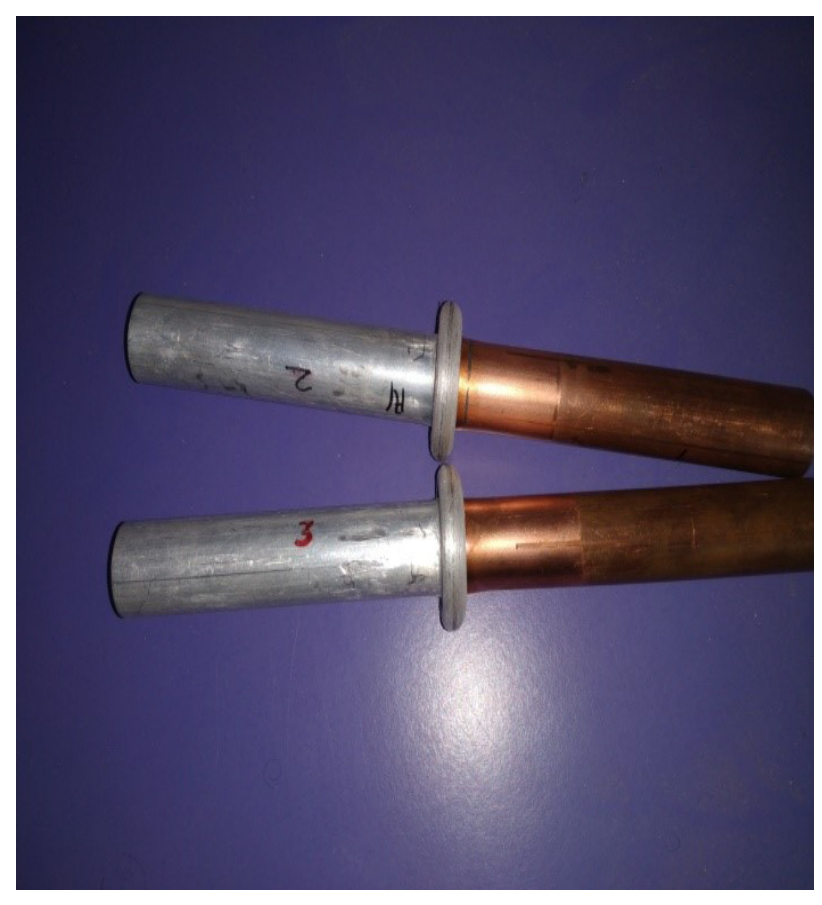

Fig.2.0 Experimental run 2 (More Losses)

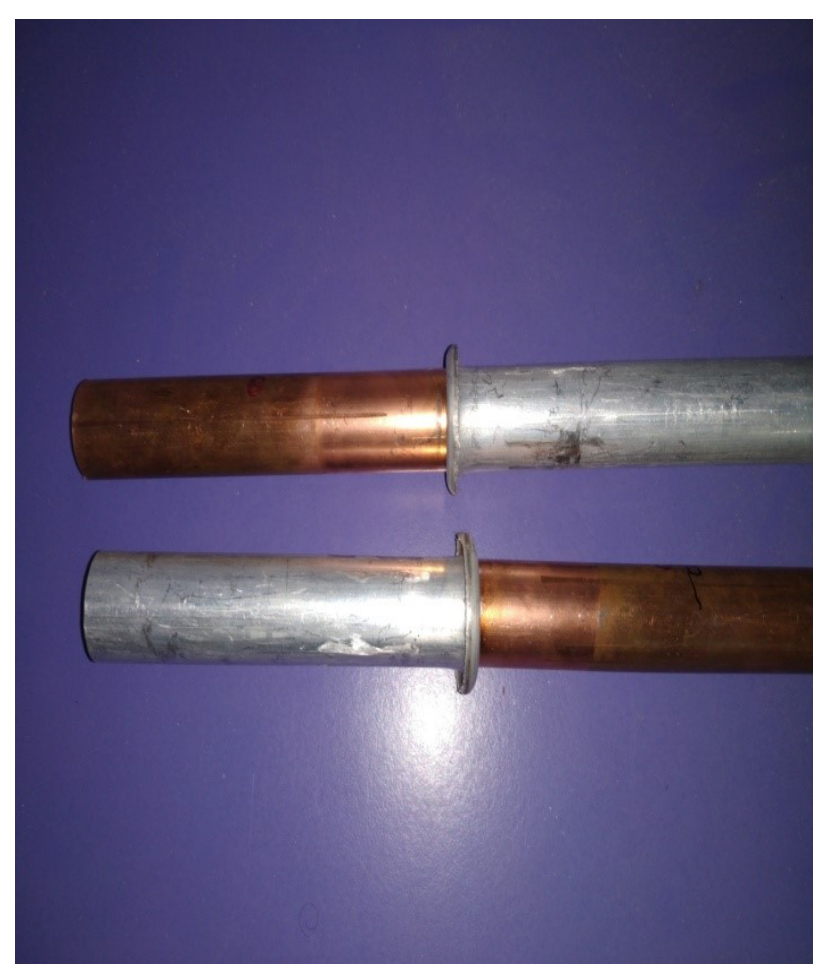

Fig. 3.0 Experimental run 3 (less losses)

AA6063 successfully welded with copper using friction pressure of $48 \mathrm{Kg} / \mathrm{mm}^{2}$ and upset pressure of 97 $\mathrm{kg} / \mathrm{mm}^{2}$ at Friction time of $1 \mathrm{sec}$ and upset time $3 \mathrm{sec}$. and spindle rotation speed SS 1800 RPM.

\subsection{Ultimate Tensile Strength (UTS) Testing}

Friction welded joints obtained from process parameters set 2 and set 3 are tested for measuring its UTS. For measuring UTS testing specimen prepared as per ASM standards specimen diameter set to $12.5 \mathrm{~mm}$ and testing performed on friction welded joint.

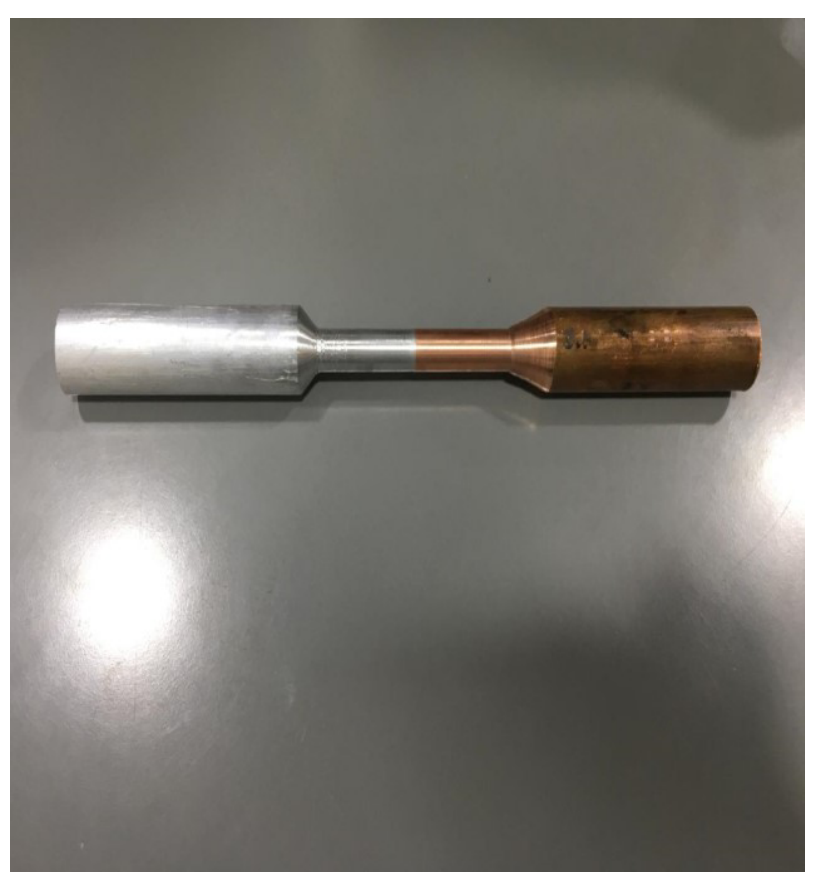

Fig. 5.0 Tensile Test Specimen

\subsection{Bending test}

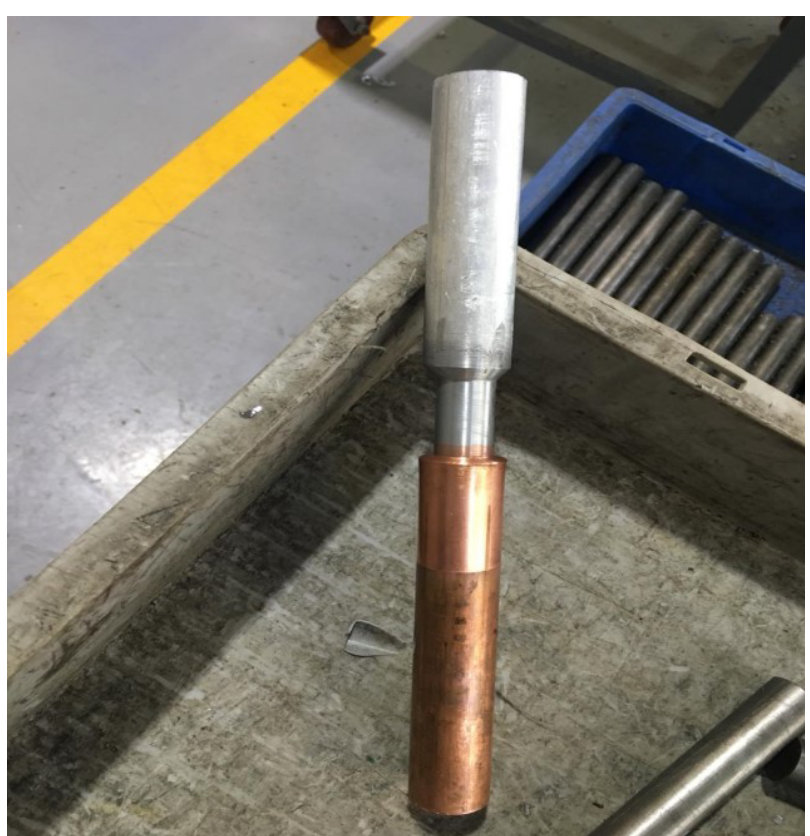

Fig. 6.0 Bending Test Specimen 
Bending test is performed for investigating the strength of IMC layers formed at welded joint interface. Bending test performed on samples welded using Friction Time of $1 \mathrm{Sec}$, Upset Pressure $97 \mathrm{~kg} / \mathrm{mm}^{2}$ and Friction Pressure of $48 \mathrm{Kg} / \mathrm{mm}^{2}$. Bending test performed at $90^{\circ}$ all the specimens welded at given set of process parameters tested for above bending test. All Samples failed the bending test.

\section{Results and Discussion}

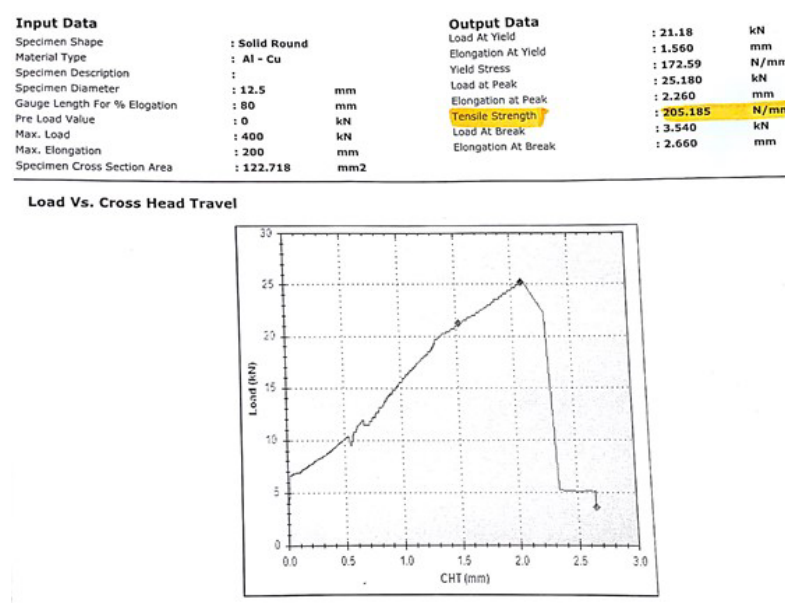

Fig.8.0 UTS test report of second trail run (205.185Mpa)

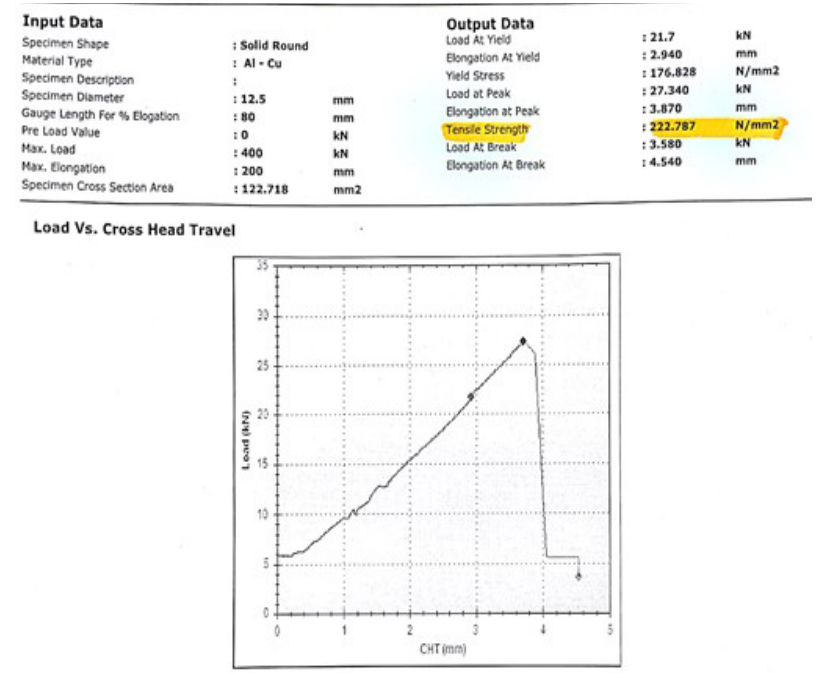

Fig.9.0 UTS test report of second trail run(222.7Mpa)

\subsection{Effect of Process Parameters}

Weld joint strength Increases with increase in Friction Time and Upset Pressure up to certain limit. Insufficient weld time results in weak friction welded joint. For first trail run Friction Time (FT) 0.5 Seconds failed to join Al6063 with Copper, increase in Friction Time will form adequate Friction Welded joint. This is proved from later two set of experimentations.
Upset pressure directly proportional to UTS of weld joint up to certain limit as shown in Fig. 8 and Fig.9. From this study it has been observed that Variation in Upset Pressure and Friction Time are contributing dominantly as compared to other process parameters of RFW process.

Friction Time (FT), Friction Pressure (FP) and Upset Pressure (UP) varied keeping other parameters constant and through this research work inferences can be drawn that this parameters are dominant process parameters and have more influence on weld strength. For joining dissimilar material using RFW and obtaining adequate tensile strength process parameters should be selected from above range to achieve good tensile strength of joint.

\section{Conclusions}

1. Experimentation shows that less friction time $(0.5 \mathrm{Sec})$ forms inadequate IMC layer results in failed friction weld joints.

2. Ultimate Tensile Strength of $205.185 \mathrm{MPa}$ obtained for friction welded specimen welded with optimised process parameters given in Table No.2.0.

3. For Friction welded joint welded with process parameters given in Table 2.0 More flash produced at joint. Due to excess flash formation considerable losses are observed (actual measured losses $12.3 \mathrm{~mm}, 15.4 \mathrm{~mm}, 15.3 \mathrm{~mm}$, $16.6 \mathrm{~mm})$ resulted in final length of work piece after welding (268.4 $\mathrm{mm}$, .

4. Ultimate Tensile Strength of $222.787 \mathrm{MPa}$ obtained with third set of process parameters given in Table 3.0. This is maximum strength achieved as in respect to base metal strength. Obtained UTS value clearly states that tensile strength of friction welding joint can be increased by increasing friction and Upset pressure up to threshold value.

5. Less flash formation takes place when Al6063 joined with Copper using Process Parameter set given in Table 3.0. In this welding less losses observed (actual measured losses $4.3 \mathrm{~mm}$, $5.2 \mathrm{~mm}, 6.7 \mathrm{~mm}, 3.4 \mathrm{~mm}$ ) resulted in Final length of work piece after welding (278.4mm, 276.3, 276.4, $277.5 \mathrm{~mm})$.

6. In this research work UTS of 205.185 MPa and 222.787 MPa observed this strength is greater than previous research work studied related to joining of dissimilar metals to Aluminium alloy using Rotary Friction Welding Process. 
Authors would like to express their sincere gratitude towards FWT Friction Welding Technology and Mr.YatinTambe for providing support for conduction of Experiments.

\section{References}

1. Radosław Winiczenkoa, Olgierd Gorochb, Anna Krzynska , Mieczysław Kaczorowski 2017, Friction welding of tungsten heavy alloy with Aluminum Alloy 6063alloy, Journal of Materials Processing Technology 246, 42-55, (2017).

2. C. Meengam, S. Chainarong, P. Muangjunburee, Friction Welding of Semi-Solid Metal 7075 Aluminum Alloy 6063Alloy, Materials Today Proceedings, 4 ,1303-1311, (2017).

3. M. Meisnar, S. Baker, J.M. Bennett, A. Bernad, A. Mostafa, S. Rescha, N. Fernandes, A. Norman Microstructural characterization of rotary friction welded AA6082 and Ti-6Al-4V dissimilar joints, Materials and Design, 132, 188-197, (2017).

4. Tolga Dursun, Costas Soutis, Recent developments in advanced aircraft Aluminum Alloy 6063alloys, Materials and Design 56 (2014) 862-871, (2014).

5. MuminSahin, Joining of Aluminum Alloy 6063and copper materials with friction welding, Springer-Verlag London Limited, (2010).

6. R.Paventhan,P.R.Lakshminarayanan, V Balasubramanian, Optimization of Friction Welding Process Parameters for Joining Carbon Steel and Stainless Steel, Science Direct International Journal of Iron and steel, 19: 6671,(2012).

7. Wenya Li, Achilles Vairis, Michael Preuss\&Tiejun Ma, Linear and rotary friction welding review, Taylor \&francis International Materials Reviews,(2016).

8. Nirmal S. Kalsi, Vishal S. Sharma, A statistical analysis of rotary friction welding of steel with varying carbon in workpieces, Springer-Verlag London Limited,(2011).

9. S.D. Meshram,T. Mohandas, G. Madhusudhan, Reddy Friction welding of dissimilar pure metals, Journal of Materials Processing Technology, 184 330-337.

10. J.Romero, M.M. Attallah,M. Preuss, M. Karadge S.E. Bray Effect of the forging pressure on the microstructure and residual stress development in $\mathrm{Ti}-6 \mathrm{Al}-4 \mathrm{~V}$ linear friction welds, Science direct

Acta Materialia, 57, 5582-5592,

(2009).

11. EmelTaban, Jerry E. Gould, John C. Lippold, Dissimilar friction welding of 6061-T6 Aluminum Alloy 6063and AISI 1018 steel: Properties and microstructural characterization, Materials and Design 31, 2305-2311, (2010).

12. Mumin Sahin, Evaluation of the joint-interface properties of austenitic-stainlesssteels (AISI 304) joined by friction welding, Mater. Des. 28, 2244-2250, (2007).

13. Fukumoto S., Tsubakino H., Okita K., Aritoshi M., Tomita T., Friction welding process of 5052 aluminium alloy to 304 stainless steel. Materials Science and Technology, 15(9), 1080-1086,(1999).

14. Li P,Li X, Xiong J, Zhang F, Liang L, A study of the mechanisms involved in initial friction process of continuous drive friction welding, Journal of Adhesion Science and Technology 29(12), 1246-12,(2015).

15. Lee WB, Bang KS, Jung SB, Effects of intermetallic compound on the electrical and mechanical properties of friction welded $\mathrm{Cu} / \mathrm{Al}$ bimetallic joints during annealing, $J$ Alloy Compd, 390(1-2), 212-219,(2005).

16. M. Sahin, Evaluation of the joint-interface properties of austenitic-stainless steels (AISI 304) joined by friction welding, Mat. Design, 28(7), 2244-2250, (2007).

17. C. Shanjeevi, S. Satish Kumar, P. Sathiya, Multi-objective optimization of friction welding parameters in AISI 304L austenitic stainless steel and copper Joints, Proc. Inst. Mech. Eng. Part B 230, 449-457, (2014). 